\title{
PROLACTIN RELEASE IN CATTLE
}

\author{
H. KARG AND D. SCHAMS \\ Institut für Physiologie, Technische Universität München, \\ 805 Freising-Weihenstephan, Germany
}

The cow has been specifically selected for lactational performance. It has no lactational anoestrus and the simultaneous reproductive ability and milk yield have not only scientific interest but economic importance too. We have no evidence of a luteotrophic action of prolactin (Hoffmann, Schams, Bopp, Ender, Giménez \& Karg, 1974) in this species such as has been shown in some others. Furthermore, mammary cancer, one motivation for the increasing amount of work devoted to studies on prolactin in man, has not been recorded in the cow.

\section{RADIOIMMUNOASSAY FOR BOVINE PROLAGTIN}

In 1969 , a specific radioimmunoassay for bovine prolactin using NIH-P-B (biological activity 19.9 i.u./mg) as antigen was developed (Schams \& Karg, 1969). In this system there were no cross reactions with growth hormone or other pituitary hormones.

\section{SPECIFIC INHIBITION OF PROLACTIN RELEASE}

It has been shown that some ergot alkaloids have an inhibitory effect on prolactin release in rats (Meites \& Nicoll, 1966). In the cow, 2-bromo- $\alpha$-ergocryptine-methansulphonate (CB-154: Sandoz, Basle) not only depressed the prolactin level in each experiment but also had a significant influence on the milk yield. Independent of the extreme extent of the prolactin inhibition there were distinct differences concerning the influence of the drug on lactation, whether the inhibitor was applied before or during the onset of lactation (lactogenesis) or later during already established lactation (galactopoiesis) (Karg, Schams \& Reinhardt, 1972; Schams, Reinhardt \& Karg, 1972; Textfig. 1).

Not only is the onset of lactation depressed by CB-154 but the composition of colostrum is altered also. In addition to a decrease of lactose and increase of protein concentration, it was found, by means of electrophoretic analysis, that the casein fraction was abnormal (O. Kirchmeier, personal communication). Summarizing a series of results it seems that the depressant effect on lactogenesis was stronger and more continuous the earlier the treatment was commenced before parturition (hence perhaps interfering with mammogenesis too). The inhibition of prolactin release during galactopoiesis had only a minor effect on milk yield and no such effect on milk composition. We conclude that prolactin plays a rather more essential part in the hormonal complex responsible for mammogenesis/lactogenesis than for galactopoiesis, at least in the cow. 

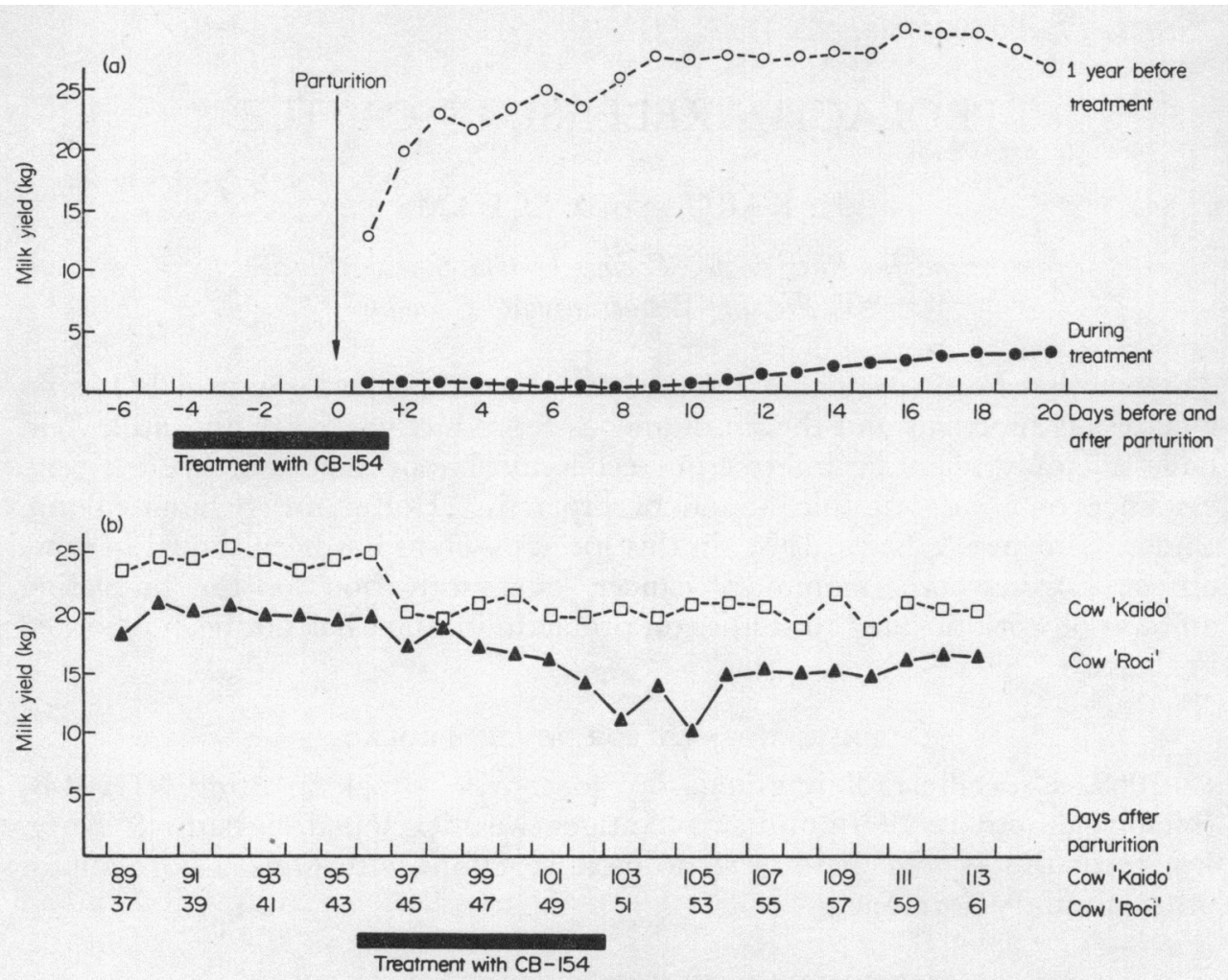

TEXT-FIG. 1. The influence of treatment with CB-154 on (a) lactogenesis and (b) galactopoiesis in cows.

THE STIMULATION OF IMMEDIATE PROLACTIN RELEASE

The question is: are there any adequate stimuli in the physiological sense and what is a 'specific trigger' for the release? Since it is known that all kinds of stress lead to prolactin release (Johke, 1970; Tucker, 1971; Raud, Kiddy \& Odell, 1971; Schams, 1973) very carefully controlled experiments are necessary to answer this question. This includes selection of individuals (animal and human) and a careful look at any side effects. For example we could demonstrate a strong prolactin response following $30 \mathrm{mg}$ prostaglandin $F_{2 \alpha}$ given intravenously. It rather looked like a strong vegetative stressor since urination, defaecation, salivation and restlessness were also observed. Nevertheless, current experiments with a moderate dose of an analagous compound indicate prolactin release although no obvious vegetative symptoms were exhibited. Hence the question of classification of such compounds in regard to prolactin release challenges further research.

Quick reproducible reactions without side effects are obtained by suckling and by milking, a phenomenon which has been well established also by several groups (Johke, 1969, 1970; Karg \& Schams, 1970; Fell, Beck, Blockey, Brown, Catt, Cumming \& Goding, 1971; Tucker, 1971; Koprowski \& Tucker, 1971; Koprowski, Convey \& Tucker, 1971; Schams \& Böhm, 1972; Schams, 1972a; Reinhardt \& Schams, 1974). Examples from our experiments are summarized 


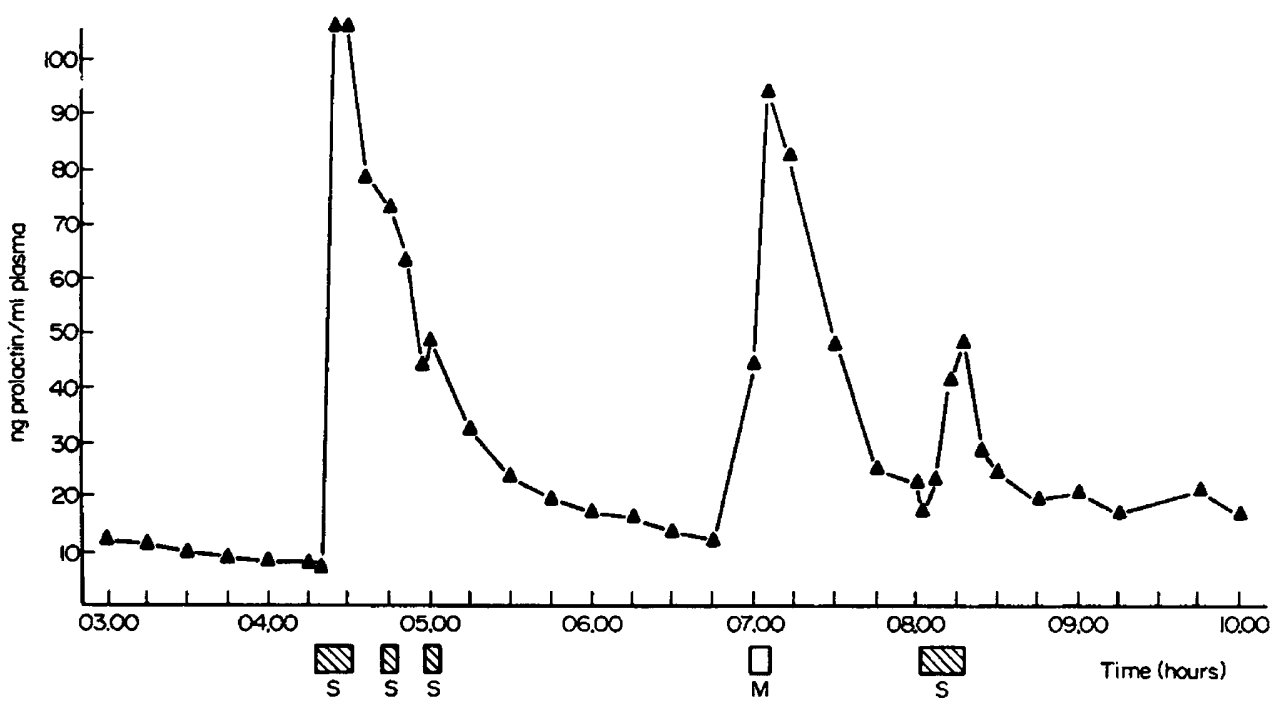

TEXT-FIG. 2. The effect of frequent suckling (S) and milking (M) on prolactin response.

in Text-fig. 2. If the intervals between suckling and milking are too short, there is evidence of a certain refractory effect which temporarily suppresses a full prolactin response. Furthermore, it could be shown that mechanical stimulation of the teats acts as a highly potent stimulus for prolactin release especially in heifers, less so in cows and to a minor degree in bulls (Text-fig. 3). The teat must be considered a site of exteroreceptors of afferent nerves whose
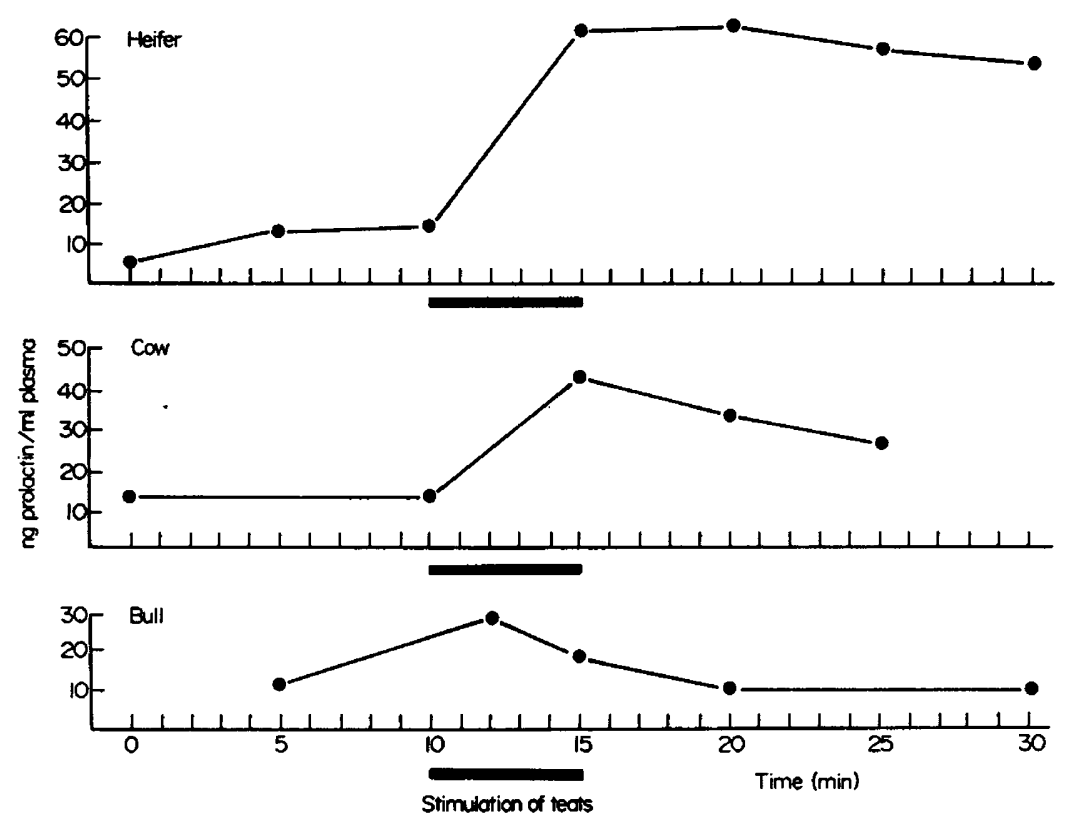

Text-Fig. 3. The effect of mechanical stimulation of the teats on prolactin release in a heifer, cow and bull. 
impulses are transformed into endocrine responses by the central nervous system. So massage of the udder, washing of the teats and a short premilking before actual milking lead to an increase of prolactin in most cows. A very short release of prolactin can also be detected after rectal massage of the cervix and of the vagina.

Since similar manipulations are known to cause oxytocin release in cows (Hays \& VanDemark, 1953) and sheep (Roberts \& Share, 1968), the question arose as to whether the effect on prolactin is mediated by oxytocin. In a series of experiments we administered 5 to 160 i.u. oxytocin to provoke prolactin release. The amount of $160 \mathrm{i}$.u. is clearly beyond a physiological dose, but up to

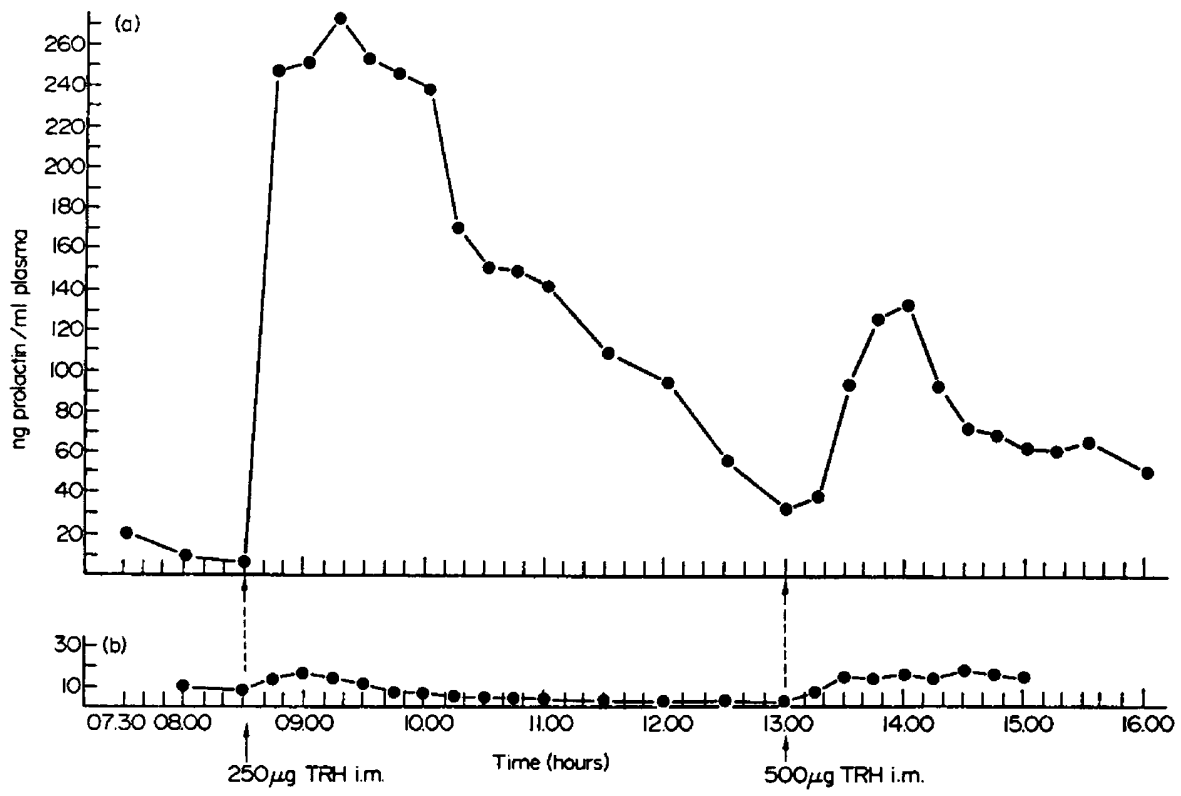

TexT-FIG. 4. The release of prolactin in cows in response to intramuscular injection of TRH (a) alone or (b) after pretreatment with the prolactin inhibitor CB-154.

80 i.u. there were no responses. We assume that the concept of Tindal \& Knaggs (1969) based on rabbits is also valid for the bovine species. Identical stimuli may be transmitted by identical afferent pathways but after the division in the central nervous system there are independent pathways for the final effects of prolactin and oxytocin release.

Further factors of hypothalamic origin were included in our studies. The decapeptide LH/FSH-RH, synthesized from Farbwerke Hoechst (Geiger, König, Wissmann, Geisen \& Enzmann, 1971) according to the structure found by Matsuo, Baba, Nair, Arimura \& Schally (1971), did not show an immediate effect on prolactin release. A smooth increase after a few hours' delay may be explained on the basis of a secondary reaction (via steroids). In contrast, the tripeptide TRH (Farbwerke Hoechst), synthesized according to the structure found by Folkers, Enzmann, Bøler, Bowers \& Schally (1969), was shown to have an immediate effect on prolactin release (Text-fig. 4). Since the prolactin 
release triggered by TRH was inhibited by the compound 2-Br- $\alpha$-ergocryptinemethansulphonate (Schams, 1972b; Schams, Reinhardt \& Karg, 1973) we are in favour of the idea that the inhibitor is active on the pituitary rather than at the hypothalamic level.

Since the tripeptide did show at least TSH- and prolactin-releasing properties we assume that we have obtained the key to manipulate the two hormones which are supposed to contribute to the lactogenic and galactopoietic complex, respectively. In consequence we started three series of experiments to evaluate the effect of TRH on milk yield.

(1) There was no positive effect ( 6 or 12 weeks post partum) during or after treatment when lactating cows were given $2 \times 500 \mu \mathrm{g}$ TRH/day intramuscularly for 2 weeks. This is in agreement with similar results of Kelly, Bedirian, Baker \& Friesen (1973).

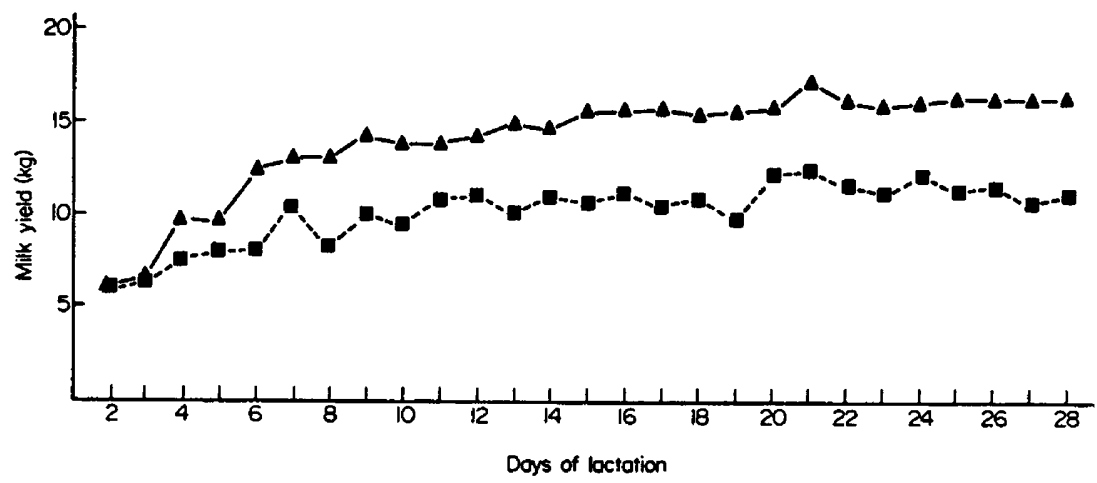

TExr-FIG. 5. The effect on lactogenesis of TRH treatment $(2 \times 250 \mu \mathrm{g} /$ day $)$ for 20 days beginning 15 days before parturition. Each point represents the mean values of two cows, each one of a pair of identical twins. $\Delta$, TRH treatment; $\square$, saline treatment.

(2) A treatment using the same dose around the time of onset of lactation in cows ( 8 days ante partum up to 8 days post partum) resulted in a 10 to $30 \%$ increase of the first 20 days milk yield compared with the performance 1 year before (Schams, 1973; Schams et al., 1973).

(3) Most encouraging were the experiments with heifers which received, during the initial stage of lactogenesis, a dose of $2 \times 250 \mu \mathrm{g} /$ day from 15 days ante partum until 5 days post partum. The preliminary results of an experiment, carried out with identical twins (in co-operation with Dr Andreae from the Max-Planck-Institut für Tierzucht, Trenthorst), showed an enlargement of the udder volume of 39 to $48 \%$ and a similarly large increase in milk yield (Text-fig. 5).

Essentially, the results from experiments (1) to (3) support the importance of prolactin primarily for mammogenesis and lactogenesis as already concluded from the experiments with the inhibitor.

The onset of lactation, normally linked with parturition, is deemed to be provoked by certain shifts of the endocrine balance, mainly of the steroid hormones. Progesterone withdrawal is suggested as being an immediate trigger for lactogenesis (Kuhn, 1970). We therefore evaluated prolactin release in the cow under the influence of oestradiol-17 $\beta$ and progesterone. 
The relationship of the feedback of oestrogens (partly counteracted by progesterone) to prolactin release has been previously investigated in several rat experiments (Chen \& Meites, 1970) in which oestradiol benzoate implants were used. Our experiments were characterized by the application of the biological compound by infusion techniques and the measurement of the immediate response in vivo (Schams \& Karg, 1972; Schams et al., 1974). With female and male (i.e. in the absence of endogenous ovarian hormones) cattle, we found that prolactin secretion is suppressed rather than enhanced during oestrogen infusion and that it is triggered by cessation of infusion, as long as the doses applied are not too high (Text-fig. 6). Progesterone seemed to act in

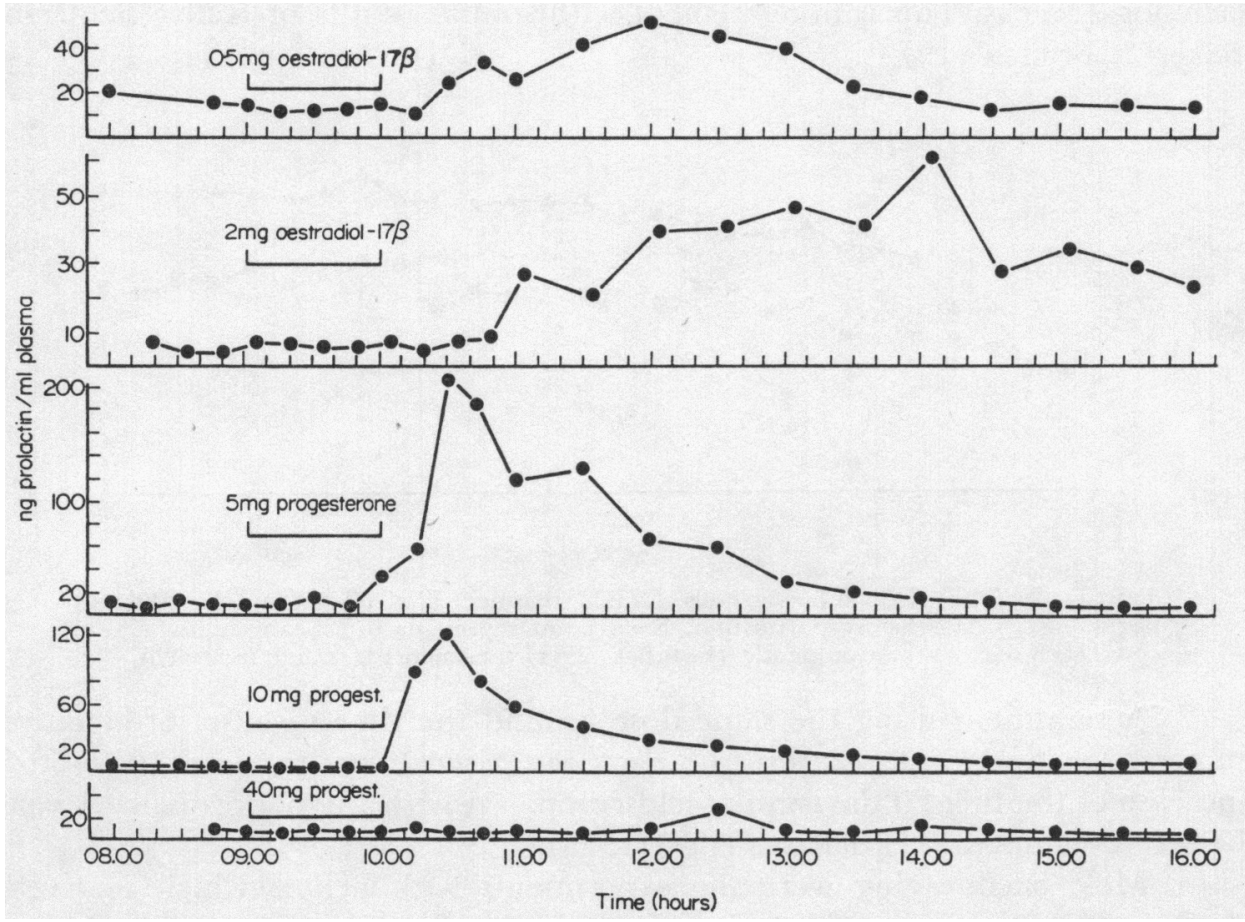

TEXT-FIG. 6 . The influence of infusions of oestradiol-17 $\beta$ and progesterone on prolactin release in bulls.

the same negative dose-dependent manner and the lowest dose $(5 \mathrm{mg})$ caused a more marked prolactin increase than higher doses (10 or $40 \mathrm{mg}$ ). The prolactin-inhibiting effect of high levels of these hormones and the rather stimulating effect of the low level is in agreement with the assumed effect of these steroids in triggering lactation, but also in accordance with the general phenomenon of positive or negative feedback of these steroids on other pituitary hormones.

\section{PHYSIOLOGICAL FLUCTUATIONS}

With the knowledge of the feedback of ovarian hormones on prolactin release we are challenged to explain some of the physiological fluctuation of the 
prolactin level as a secondary result of such endogenous relationships, not necessarily indicative of the functional relationships of prolactin. From this point of view we should like to have a closer look at the prolactin secretion patterns during the oestrous cycle and during parturition. It has been shown in several species that there is an increased prolactin release during prooestrus and oestrus in the rat (Niswender, Chen, Midgley, Meites \& Ellis, 1969; Sinha \& Tucker, 1969) and in the ewe (Reeves, Arimura \& Schally, 1970; Bryant, Greenwood, Kann, Martinet \& Denamur, 1971). The results in the cow are contradictory. It is quite probable that, in this species also, increases in prolactin occur some days before oestrus and that they persist

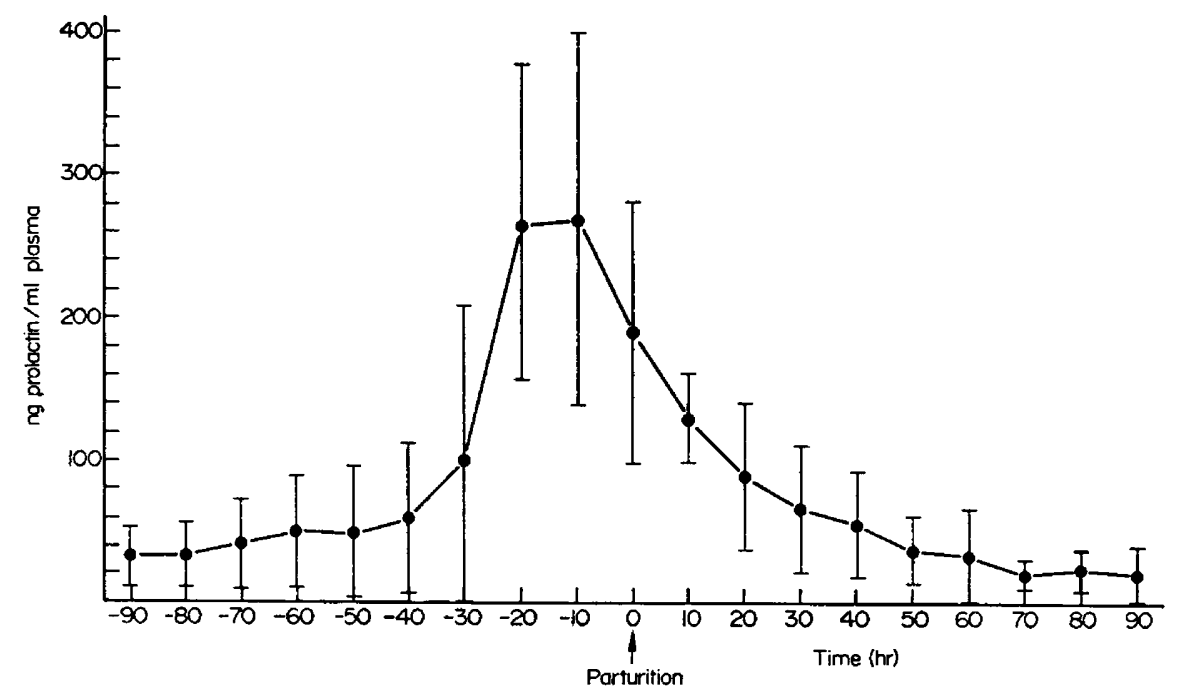

TEXT-FIG. 7. The release of prolactin about the time of parturition. Each point represents the mean value \pm S.D. of nine cows.

until the day of ovulation as shown by the reports of Sinha \& Tucker (1968, 1969), Swanson \& Hafs (1971), Raud et al. (1971) and our own unpublished experiments with heifers in contrast to earlier findings on cows (Schams \& Karg, 1970). Since we could not find any oestrous cycle disorders in cows after use of the prolactin inhibitor, and as there is no evidence of luteotrophic action of prolactin in this species (Hoffmann et al., 1974), we rather suppose these prolactin surges to be non-functional, perhaps being mediated by the steroid dynamics around oestrus.

The most distinct prolactin elevation occurs around parturition (Schams \& Karg, 1969, 1970; Johke, 1971; Ingalls, Convey \& Hafs, 1973; Text-fig. 7). We are also tempted to explain this peak symptomatically rather than functionally for the following reasons: the progesterone and oestrogen dynamics resemble the pattern for a pre-partum prolactin release but other more obvious stresses, genital distention, endogenous prostaglandin activation, etc. may be within the complex. We do not interpret this peak as being functional or essential either for the onset of lactation or for parturition (Karg \& Schams, 1970; Schams et al., 1972). Premature lactation could be initiated by corticoid 
treatment before parturition, but the prolactin peak remained associated with parturition. When the prolactin peak was suppressed by applying the prolactin inhibitor before parturition, delivery still occurred normally.

Some investigators have suggested a correlation between the lactational stage or individual yield performance and the prolactin level (Johke, 1970; Fell et al., 1971), but no seasonal influences were taken into account. Our earlier observation (Schams \& Karg, 1970; Karg \& Schams, 1970), that the 'pacemakers' for the basic level of prolactin are primarily the seasonal rhythms, is being confirmed. Schams (1972a) and Schams \& Reinhardt (1974) provided convincing evidence that climatic factors influence the basal prolactin levels in male and female individuals from birth to adulthood regardless of sex, age

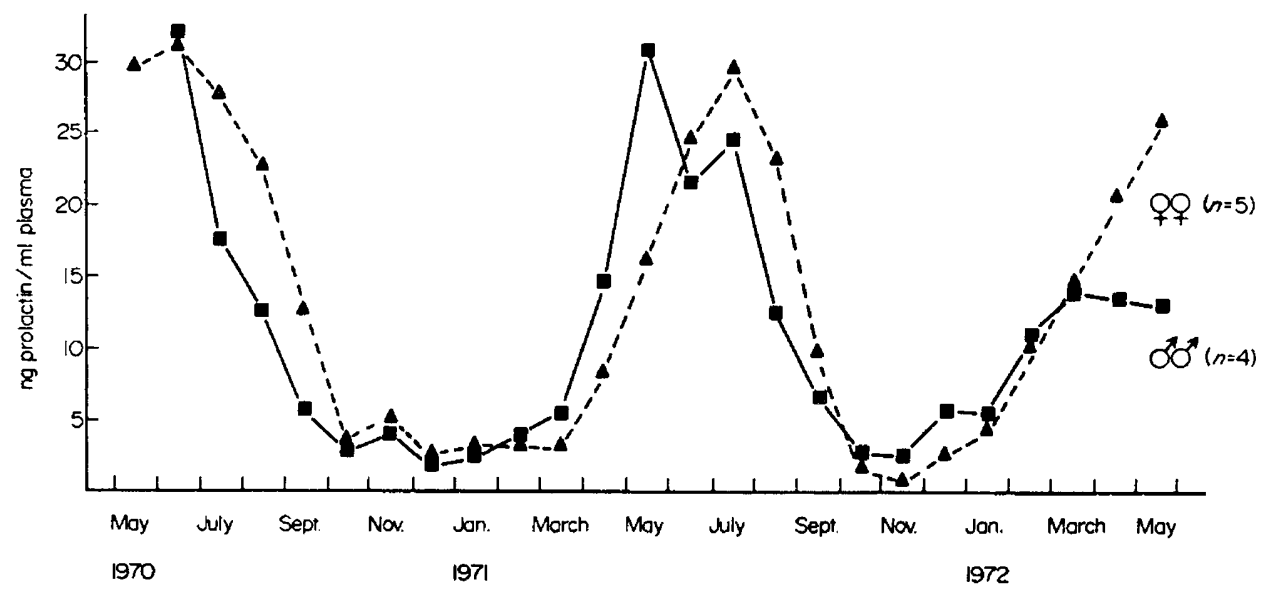

TEXT-FIG. 8. Seasonal variations in basal prolactin levels in non-lactating male ( $\boldsymbol{\square}$ ) and female $(\Lambda)$ cattle from birth to puberty.

and lactation. Since there was a significant positive correlation of daylight length with the basal prolactin level, day length is presumably the essential climatic parameter (Text-fig. 8). The circadian fluctuations observed in male and female cattle (Schams \& Karg, 1970; Koprowski, Tucker \& Convey, 1972), seemed to be independent of any feeding rhythm or housing pattern. Fasting seemed not to interfere with the rhythms of prolactin release, but lower amplitudes (Schams \& Karg, 1970; McAtee \& Trenkle, 1971) were observed during consecutive days. The observation of Stupnicki, Madej \& Dobrowolski (1973), that the circadian rhythm of the prolactin level is less pronounced in cows during oestrus but most significant in ovariectomized cows 4 to 6 weeks after operation, is of interest.

\section{GONGLUSION}

Several 'physiological fluctuations' of the prolactin level in peripheral blood have dubious functional implications. Hence some of these may be explained symptomatically rather than functionally. Concerning the basal prolactin level, the correlation with seasonal variations is dominant but circadian rhythmicity also has to be taken into account. In regard to exteroceptive stimuli, 
stressful situations are likely to include prolactin release in the complex of reactions. In the physiological sense the increase of prolactin secretion after stimulation of the teats is probably the most specific. There is a reciprocal dose/response relationship between ovarian oestrogens and progesterone administered and the immediate prolactin release. A most efficient procedure for demonstrating a positive influence on prolactin secretion is treatment with the synthetic tripeptide, TRH. A specific inhibitor of prolactin release is 2-Br- $\alpha$-ergocryptine-methansulphonate. Experiments using these compounds were helpful in elucidating the physiological participation of prolactin in mammogenesis and lactogenesis in which it appears to be essential, in galactopoiesis in which it appears to play a minor rôle and as a luteotrophin, which seems to be of no importance in the bovine species. The use of these compounds for manipulation of the onset of lactation and milk yield should be considered to be of practical interest.

\section{ACKNOWLEDGMENTS}

We should like to thank the Farbwerke Hoechst (Frankfurt) for supplying us with the synthetic releasing hormones LH-RH and TRH, the Sandoz Company (Basle) for supplying us with CB-154 and oxytocin (Sandozinon) and the National Institutes of Health for providing bovine prolactin NIH-P-B ${ }_{2}$.

\section{REFERENGES}

Bryant, G. D., Greenwood, F. C., Kann, G., Martinet, J. \& Denamur, R. (1971) Plasma prolactin in the oestrous cycle of the ewe: effect of pituitary stalk section. F. Endocr. 51, 405 .

Chen, C. L. \& Mertes, J. (1970) Effects of thyroxine and thiouracil on hypothalamic PIF and pituitary prolactin levels. Proc. Soc. exp. Biol. Med. 131, 576.

Fell, L. R., Beck, G., Blockey, M. A. B., Brown, J. M., Catt, K. J., Cumming, I. A. \& Goding, J. R. (1971) Prolactin in the dairy cow during suckling and machine milking. J. Reprod. Fert. 24, 144.

Fol.kers, K., Enzmann, F., Bøler, J., Bowers, G. Y. \& Schally, A. V. (1969) Discovery of modification of the synthetic tripeptide-sequence of the thyrotropin releasing hormone having activity. Biochem. biophys. Res. Commun. 37, 123.

Geiger, R., König, W., Wissmann, H., Geisen, K. \& Enzmann, F. (1971) Synthesis and characterisation of a decapeptide having LH-RH/FSH-RH activity, Biochem. biophys. Res. Commun. 45, 767.

HAYs, R. L. \& VANDEMARK, N. L. (1953) Effect of stimulation of the reproductive organs of the cow on the release of an oxytocin-like substance. Endocrinology, 52, 634 .

Hoffmann, B., Schams, D., Bopp, R., Ender, M. L., Giménez, T. \& KarG, H. (1974) Luteotrophic factors in the cow: evidence for LH rather than prolactin. 7. Reprod. Fert. 40, 77.

Ingalls, W. G., Convex, E. M. \& Hafs, H. D. (1973) Bovine serum LH, GH, and prolactin during late pregnancy, parturition and early lactation. Proc. Soc. exp. Biol. Med. 143, 161.

JoHke, T. (1969) Prolactin release in response to milking stimulus in the cow and goat estimated by radioimmunoassay. Endocr. jap. 16, 179.

JoHKE, T. (1970) Factors affecting the plasma prolactin level in the cow and the goat as determined by radioimmunoassay. Endocr. jap. 17, 393.

JoHke, T. (1971) Changes of plasma prolactin level during late pregnancy and early lactation in the goat and the cow. Fap. F. zootech. Sci. 42, 173.

Karg, H. \& Schams, D. (1970) Prolactin levels in bovine blood under different physiological conditions. In Lactation, p. 141. Ed. I. R. Falconer. Butterworths, London.

Karg, H., Schams, D. \& Reinhardt, B. (1972) Effects of 2-Br- $\alpha$-ergocryptine on plasma prolactin level and milk yield in cows. Experientia, 28, 574 .

Kelly, P. A., Bedirian, K. N., Baker, R. R. D. \& Friesen, H. G. (1973) Effect of synthetic TRH on serum prolactin, TSH and milk production in the cow. Endocrinology, 92, 1289.

Koprowski, J. A., Convey, E. M. \& TuCkER, H. A. (1971) Response of serum prolactin to stimulation of the udder or brisket. F. Dairy Sci. 54, 769. 
Koprowski, J. A. \& TuCKer, H. A. (1971) Failure of oxytocin to initiate prolactin or luteinizing hormone release in lactating dairy cows. F. Dairy Sci. 54, 1675.

Koprowski, J. A., Tucker, H. A. \& Convey, E. M. (1972) Prolactin and growth hormone circadian periodicity in lactating cows. Proc. Soc. exp. Biol. Med. 140, 1012.

Kunn, N. J. (1970) Control of lactogenesis and lactose biosynthesis. In Lactation, p. 161. Ed. I. R. Falconer. Butterworths, London.

McAtre, J. W. \& TRenkLe, A. (1971) Effects of feeding, fasting, glucose or arginine on plasma prolactin levels in the bovine. Endocrinology, 89, 730.

Matsuo, H., Baba, Y., Nair, R. M. G., Arimura, A. \& Schally, A. V. (1971) Structure of the porcine LH- and FSH-releasing hormone. I. The proposed amino acid sequence. Biochem. biophys. Res. Commun. 43, 1334.

Merres, J. \& Nicoll, C. S. (1966) Adenohypophysis: prolactin. A. Rev. Physiol. $28,57$.

Niswender, G. D., Chen, G. L., Midgley, A. R., Jr, Meites, J. \& Ellis, S. (1969) Radioimmunoassay for rat prolactin. Proc. Soc. exp. Biol. Med. 130, 793.

RAUd, H. R., Kiddy, G. A. \& Odeli, W. D. (1971) The effect of stress upon the determination of serum prolactin by radioimmunoassay. Proc. Soc. exp. Biol. Med. 136, 689.

Reeves, J.J., Arimura, A. \& Schally, A. V. (1970) Serum levels of prolactin and luteinizing hormone (LH) in the ewe at various stages of the estrous cycle. Proc. Soc. exp. Biol. Med. 134, 938.

Reinhardt, V. \& Schams, D. (1974) Analysis of teat stimulation as specific stimulus for prolactin in cattle. Neuroendocrinology (in press).

Roberts, J. S. \& Share, L. (1968) Oxytocin in plasma of pregnant, lactating and cycling ewes during vaginal stimulation. Endocrinology, 83, 272.

Schams, D. (1972a) Prolactin levels in bovine blood, influenced by milking manipulation, genital stimulation and oxytocin administration with specific consideration of the seasonal variation. Acta endocr., Copenh. 71, 684.

Schams, D. (1972b) Releasing effect of TRH in the bovine and their depression by a prolactin inhibitor. Hormone Metab. Res. 4, 405.

Schams, D. (1973) Untersuchungen über Prolaktin beim Rind. Habilitationsschrift, Technische Universität München-Weihenstephan.

Schams, D. \& Böнm, S. (1972) Einfluss von Melkreiz, Manipulationen am Euter, Genitalreizung und exogener Oxytocinzufuhr auf den Blutspiegel von Prolaktin beim Rind. Milchwissenschaft, 27, 300.

Schams, D. \& Karg, H. (1969) Radioimmunologische Bestimmung von Prolaktin im Blutserum vom Rind. Milchwissenschaft, 24, 263.

Schams, D. \& KARG, H. (1970) Untersuchungen über Prolaktin im Rinderblut mit einer radioimmunologischen Bestimmungsmethode. Zentbl. VetMed. 17, 193.

Schams, D. \& KaRG, H. (1972) The immediate response of the prolactin level to oestrogen infusions in dairy cows. Acta endocr., Copenh. 69, 47.

Schams, D. \& Reinhardt, V. (1974) Influence of the season on plasma prolactin level in cattle from birth to maturity. Hormones (in press).

Schams, D., Reinhardt, V. \& Karg, H. (1972) Effects of 2-Br- $\alpha$-ergocryptine on plasma prolactin level during parturition and onset of lactation in cows. Experientia, 28,697.

Schams, D., Reinhardt, V. \& Karg, H. (1973) Spezifische Manipulation der Prolaktinsekretion beim Rind und deren Auswirkung auf die Laktation. Milchwissenschaft, 28, 7.

Schams, D., Reinhardt, V. \& Karg, H. (1974) The immediate response of the plasma prolactin level to oestrogen and progesterone infusions in bulls. Acta endocr., Copenh. 76, 242.

SinhA, Y. N. \& TuCKER, H. A. (1968) Mammary biochemical components and pituitary prolactin of heifers during the estrous cycle. F. Dairy Sci. 51, 957.

SinhA, Y. N. \& TUGKer, A. H. (1969) Relationship of pituitary prolactin and LH to mammary and uterine growth of pubertal rats during the estrous cycle. Proc. Soc. exp. Biol. Med. 131, 908.

Stupnicki, R., MadeJ, A. \& Dobrowloski, W. (1973) Circadian rhythm of plasma prolactin levels in cows. Proc. 7th Conf. Europ. Compar. Endocr., Budapest.

Swanson, E. W. \& Hafs, H. D. (1971) LH and prolactin in blood serum from estrus to ovulation in Holstein heifers. F. Anim. Sci. 33, 1038.

Tindal, J. S. \& Knagas, G. S. (1969) An ascending pathway for release of prolactin in the brain of the rabbit. F. Endocr. 45, 111.

Tucker, H. A. (1971) Hormonal response to milking. F. Anim. Sci. 32, Suppl. 1, 137. 